\title{
Drone brood fed supplement impacts on the folliculogenesis in growing gilts
}

\author{
Elena Kistanova $^{1 *}$, Elena Zdoroveva ${ }^{2}$, Michail Nevitov ${ }^{2}$, Aleksey Nosov $^{2}$, \\ Mikhail Vysokikh ${ }^{3,4}$, Iuliia Sukhanova ${ }^{3}$, Polina Vishnyakova ${ }^{3}$, Desislava Abadjieva ${ }^{1}$, \\ Desislava Ankova ${ }^{1}$, Pavel Rashev ${ }^{1}$, and Gennadi Boryaev ${ }^{2}$ \\ ${ }^{1}$ Institute of Biology and Immunology of Reproduction, Bulgarian Academy of Sciences, Sofia, Bulgaria \\ ${ }^{2}$ Department of Biology and Biotechnology, Penza State Agrarian University, Penza, Russia \\ ${ }^{3}$ Belozerskii Institute of Physico-chemical Biology, Moscow State University, Moscow, Russia \\ ${ }^{4}$ National Medical Research Center for Obstetrics, Gynecology and Perinatology Acad. “V. I. Kulakov”, Ministry of \\ Healthcare of Russian Federation, Moscow, Russia
}

KISTANOVA, E., E. ZDOROVEVA, M. NEVITOV, A. NOSOV, M. VYSOKIKH, I. SUKHANOVA, P. VISHNYAKOVA, D. ABADJIEVA, D. ANKOVA, P. RASHEV, G. BORYAEV: Drone brood fed supplement impacts on the folliculogenesis in growing gilts. Vet. arhiv 90, 583-592, 2020.

ABSTRACT

The biological properties of bee drone brood make it an ideal additive for growth promotion in animal husbandry instead of banned hormonal anabolics and antibiotics. However, the drone brood action on mammalian ovaries has not been well studied. The present study analyzes the impact of drone brood homogenate (DBH) in the diet of growing gilts on folliculogenesis. Large White female pigs at the age of 35 days were randomly divided into two groups of 10 animals each, and fed with the same basal diets. The experimental group was supplemented with $25 \mathrm{mg} / \mathrm{kg}$ forage of DBH for 180 days, after which the animals were slaughtered and morphometric, histological and immunohistochemical evaluation of their ovaries was performed. In addition, the expression of ovarian growth factors BMP15 and GDF9 in oocytes and cumulus cells was analyzed by RT-PCR. A significant increase in body weight and average daily gain at day 145 in the DBH-supplemented group was established. The length of the ovaries in the treated animals also was enhanced. More pools of primordial follicles, involved in intensive growth, as well as a larger diameter of primary and tertiary follicles were found in the ovaries of DBH-supplemented animals. These findings corresponded with an increase in the expression of GDF9 mRNA in the oocytes and cumulus cells. At the same time, signs of atresia in the Graafian follicles of treated animals were observed. The supplementation with DBH stimulates the early stages of folliculogenesis in gilts, but provokes atresia in the last stage of follicular development.

Key words: gilts ovary; drone brood homogenate; BMP15; GDF9

\section{Introduction}

The prohibition of the use of hormonal anabolic compounds for increasing meat yield in livestock animals has provoked a search for new alternatives based on natural products, which are safer for human and animal health. The anabolic hormonelike effects of bee drone brood (DB) have been described by several authors in Eastern European and Asian folk medicine (MEDA et al., 2004;

\footnotetext{
*Corresponding author:

Assoc. Prof. Elena Kistanova, PhD, Institute of Biology and Immunology of Reproduction, Bulgarian Academy of Sciences, Sofia, Bulgaria, Phone: +359 898225 020; E-mail: kistanova@gmail.com
} 
HUIS, 2013). Drone brood homogenate (DBH) has a rich nutritional profile, as it consists of more than $20 \%$ protein, $50 \%$ fat, many amino acids and sugars (ISIDOROV et al., 2016; SHOINBAYEVA et al., 2017), as well as a high content of water soluble B complex vitamins, considerable quantities of potassium, phosphorus, calcium and microelements such copper, iron, manganese, and selenium (NARUMI, 2004). Many beekeepers remove DB as part of a strategy to lower the population of the destructive Varroa mite ( $V$. destructor) in the hives. This results in the waste of tons of a valuable feed resource (MUTSAERS et al., 2005). The scientific data about DB supplementation in livestock animal diets is generally scarce. The androgenic and anabolic effects of Apilarnil (drone bee larvae preparation) in male broilers have been described by YÜCEL et al., (2011) and ALTAN et al., (2013). In addition, SHOINBAYEVA et al. (2015) reported the increased weight of the seminal glands and recovered sexual dysfunction in junior boars after application of an alcoholic extract of DB. Several studies have proved that DB contains the steroids estradiol, progesterone, and testosterone (BURMISTROVA et al., 2014; SHOINBAYEVA et al., 2015). However, little is known about the action of DB products on the reproductive system of female mammals. The report by SERES et al. (2013) suggests that crude drone milk (DM), which is separated from DB through elimination of the larvae and pupae, induces estrogenic and gestagenic effects in rat uteri. To date, there have been no scientific reports on the effects of whole $\mathrm{DBH}$ on ovary function in mammals.

Recent data provide evidence that nutritional stimuli can affect folliculogenesis through altered expression of members of the transforming growth factor- $\beta$ (TGF- $\beta$ ) superfamily, such as bone morphogenetic proteins (BMPs) and growth differentiation factors (GDFs) (DAOUD et al., 2012; ABADJIEVA and KISTANOVA, 2016). They are expressed in the ovaries and play essential roles in the regulation of folliculogenesis, oogenesis and ovarian functions in many species (OTSUKA et al., 2011).

The aim of the present study was to analyze whether addition of $\mathrm{DBH}$ to the diet of growing gilts affects folliculogenesis. Our investigation focused mainly on morphometric, histological and immunohistochemical evaluation of the ovaries, together with expression analysis of the ovarian growth factors GDF9 and BMP15 in gilts supplemented with DBH.

\section{Materials and methods}

Drone brood homogenate production. The homogenate was obtained from the apiary of Penza State Agrarian University. Frames with drone wax were situated in the middle of the nest of strong healthy families. The selection of drone combs was made when drone larvae reached the age of 10-12 days, after which the larvae were removed from the honeycomb, homogenized, preserved with a mixture of sorbic $(0.75 \mathrm{~g})$ and citric $(0.75 \mathrm{~g})$ acids per $100 \mathrm{~g}$ of $\mathrm{DBH}$, and stored at $-20^{\circ} \mathrm{C}$. The content of ecdysteroids in the homogenate was estimated by HPLC (Varian, Pro Star, USA) using the analytical column Diasorb 130 C16 T (BioChemMac, Russia), $20 \%$ acetonitrile as an eluent and wavelength $\lambda=$ $242 \mathrm{~nm}$. The makisterone A was used as an internal standard. The sample processing was done in accordance with LAFONT et al. (1982).

Table 1. Nutritive constituents of the basal diet

\begin{tabular}{|l|c|c|}
\hline \multirow{2}{*}{ Ingredients } & \multicolumn{2}{|c|}{ Amount, \% } \\
\cline { 2 - 3 } & $\begin{array}{c}\text { Up to 145 } \\
\text { days of age }\end{array}$ & $\begin{array}{c}\text { 145-225 days } \\
\text { of age }\end{array}$ \\
\hline Wheat & 40 & 20 \\
\hline Hull-less barley & 10 & 32 \\
\hline Hull-less oat & 15 & 20 \\
\hline Extruded wheat bran & 15 & 15 \\
\hline Flax oil cake & 5 & 5 \\
\hline Soybean meal & 10 & 5 \\
\hline Fish flour & 3 & - \\
\hline Aft chalk & 1.0 & 2.0 \\
\hline Common salt & 0.5 & 0.5 \\
\hline Premix & 0.5 & 0.5 \\
\hline Contained in 1 kg: & & \\
\hline Exchange energy, MJ & 12.6 & 12.4 \\
\hline Raw protein, g & 181 & 150 \\
\hline Calcium, g & 8.2 & 7.8 \\
\hline Phosphorus, g & 7.2 & 6.1 \\
\hline
\end{tabular}


Animals. Twenty female Large White pigs at the age of 35 days, taken from the experimental animal base of the Penza State Agrarian University, were randomly divided into two groups of 10 animals each. Both groups were fed with a standard diet for growing pigs (Table 1). Animals from the experimental group were additionally supplemented with $25 \mathrm{mg}$ of $\mathrm{DBH} / \mathrm{kg}$ of forage. The experiment was run for 180 days, which covered the whole period of sexual maturation in the pigs, and it was terminated by slaughtering. Productive parameters, such as daily weight gain and muscle loin eye area, were analyzed by standard methods (State Standard Specification R (SSS- R) 53221-2008 « Pigs for slaughter. Pork in carcasses and half carcasses.»).

The animals were reared and handled in accordance with the Veterinary Law of the Russian Federation (29/08/2014) and RF SSS 332152014(N 73-P 22.12.2014) harmonized with the European Convention "For the protection of vertebrate animals used for experimental and other scientific purposes" (ETS N 123).

The experimental protocol for this experiment was approved by the Ethics Commission of the Penza State Agrarian University (Protocol No. 1 of 08/09/2015.)

Estrus stage detection. Daily vaginal smears were obtained between days 155-165 and then stained with hematological stain. The definition of estrus cycle stages was made on the base of epithelial cell counts, their categorization and the presence of leucocytes, in accordance with ROGERS et al. (1993).

Morphometric, histological and immunohistochemical analyses of ovaries. After slaughtering, the ovaries were removed and weighed. The length and width of the ovaries in $\mathrm{cm}$ were measured with the help of a measuring scale. One ovary from each animal was processed using routine procedures for histological samples, and stained with hematoxylin. Folliculogenesis was characterized through analysis of the follicular structures, as described by GRIFFIN et al.( 2006). The diameter of the follicles was measured by tools from Image Analyzing system software on the Olympus BX51 microscope (Tokyo, Japan).
GDF9 and BMP15 protein detection was performed as previously described (ABADJIEVA and KISTANOVA, 2016). The following commercial antibodies were used: primary antibodies - rabbit polyclonal anti-GDF9 (1:100; ab93892 Abcam, USA) and anti-BMP15 (1:100; orb247897, Biorbyt, USA), secondary - anti-rabbit biotinylated antibodies (ab97049, Abcam,USA). Positive expression was defined by a brown 3,3'-diaminobenzidine (DAB, ACV500; ScyTeK, USA) precipitate, and the nuclei were stained with hematoxylin (Vector, USA). Negative controls for the staining were performed by replacing the primary antibody with irrelevant IgGs.

Oocytes collection. The cumulus-oocyte complexes (COCs) were aspirated by puncturing the visible large follicles (diameter $\geq 5 \mathrm{~mm}$ ) from the second ovary, and collected and counted using a SMZ-10 stereomicroscope (Nikon, Japan). The separation of oocytes and cumulus cells was done as described by ABADJIEVA and KISTANOVA (2016). The collected cells were stored at $-80{ }^{\circ} \mathrm{C}$ until RNA extraction.

Gene expression analysis. Total RNA was isolated from cumulus cells and oocytes by a standard protocol using a RNA Extract Reagent (Evrogen, Russia). RNA concentration and 260/280 ratio were measured with a DS-11 spectrophotometer (DeNovix, USA). The cDNA strands were synthesized by a MMLV RT kit (Evrogen, Russia), according to the manufacturer's instructions. The GDF9 and BMP15 expression in the oocytes and cumulus cells was analysed by RTPCR (DNA-Technology, Russia) with the following primer sequences:

Cyclophilin (reference gene) - F- AATGCTGGCCCCAACACA and R-TCAGTCTTGGCAGTGCAAATG; BMP15- F-TCCCAGAGGCCTGGAAGA and R-GCCTTCCGCAAAAGAAGAGA; GDF9- F-ATGTGACGGCCATCCTTCAG and R-CGATGGACATGTGAATCTCTCTCT.

The software QGENE was applied for $2^{\Delta \mathrm{Ct}}$ calculation.

Statistical methods. The data were analyzed by parametric (Student's $t$-test) and non-parametric (Mann-Whitney) statistical tests, depending on the number of samples and normality of variance distribution. 


\section{Results}

HPLC analysis showed that the DBH used for supplementation contained $0.0022 \%$ ecdysteroids per mg. The main component of that was estimated to be makisterone A $(0.0007 \%)$.

The treated animals manifested a clear tendency to have a higher life body weight (BW) and higher average daily gain (ADG) (Table 2). DBH supplementation had a stronger effect on $\mathrm{BW}$ and ADG at the initial stages of growth $(16.3 \%$ for BW and $13.3 \%$ for ADG at $90^{\text {th }}$ day). The small number of experimental animals and individual variation did not allow for obtaining a statistically significant difference in BW and ADG for the whole experimental period. However, on day 145 the BW and ADG were significantly higher in the group fed with DBH (Table 2). Additionally, the loin eye area (LEA) in treated animals tended to increase by $8.2 \%$ compared to controls (Table 2 ).
Macroscopic linear analysis showed an increase in ovary length in the treated animals, although no significant difference in ovary weight was established (Table 3).

Analysis of vaginal smears obtained between days 155-165 showed that all the animals had started cycling, but manifested different stages of the estrus cycle. Animals from the DBH-supplemented group were mainly in the proestrous stage of the cycle (predominate nucleated epithelial cells), while the control animals were mostly in the metaestrous stage (predominate leucocytes and cornified epithelial cells). This meant that DBH-treated animals were one stage behind the controls in their estrous cycle. Histological analysis of the ovaries of gilts slaughtered on days 210-215, showed that both the DBH-supplemented and the control groups had a full division of follicles from primordial to ovulatory.

Table 2. Productive parameters of the growing gilts, fed a diet supplemented with drone brood homogenate. Data are presented as a mean \pm SD; The Mann-Whitney test was used for statistical analysis; the difference is significant when $\mathrm{P}<0.05$.

\begin{tabular}{|l|c|c|c|c|c|c|c|c|}
\hline \multirow{2}{*}{ Age (days) } & 35 & \multicolumn{2}{|c|}{90} & \multicolumn{2}{|c|}{145} & \multicolumn{2}{|c|}{215} & \\
\hline Group & $\begin{array}{c}\text { Body } \\
\text { mass, kg }\end{array}$ & $\begin{array}{c}\text { Body } \\
\text { mass, kg }\end{array}$ & $\begin{array}{c}\text { Daily } \\
\text { gain, } \mathrm{g}\end{array}$ & $\begin{array}{c}\text { Body } \\
\text { mass, kg }\end{array}$ & $\begin{array}{c}\text { Daily } \\
\text { gain, g }\end{array}$ & $\begin{array}{c}\text { Body } \\
\text { mass, kg }\end{array}$ & $\begin{array}{c}\text { Daily } \\
\text { gain, g }\end{array}$ & $\begin{array}{c}\text { Loin eye } \\
\text { area, } \mathrm{cm}^{2}\end{array}$ \\
\hline Control & 10.61 & 26.43 & 319.3 & 51.8 & 409.3 & 113.1 & 568.9 & 51.5 \\
(n=10) & \pm 0.8 & \pm 2.1 & \pm 23.9 & \pm 3.3 & \pm 27.1 & \pm 7.25 & \pm 30.3 & \pm 2.7 \\
\hline Experimental & 10.87 & 30.73 & 361.9 & 58.0 & 449.1 & 121.1 & 612.2 & 55.7 \\
(n=10) & \pm 0.7 & \pm 1.5 & \pm 16.0 & \pm 2.3 & \pm 16.1 & \pm 4.7 & \pm 26.7 & \pm 3.5 \\
\hline \% to control & & 116.3 & 113.3 & 112.1 & 109.8 & 107.1 & 107.6 & 108.2 \\
\hline P-value & NS & NS & NS & 0.04 & 0.001 & NS & NS & NS \\
\hline
\end{tabular}


Table 3. Morphometric parameters of the ovaries of growing gilts supplemented with drone brood homogenate. Data are presented as a mean \pm SD; Student's $t$ - test was used for statistical analysis; the difference is significant when

$\mathrm{P}<0.05$

\begin{tabular}{|c|c|c|c|c|c|c|c|}
\hline Parameters & $\begin{array}{c}\text { Ovary } \\
\text { weight, } g\end{array}$ & $\begin{array}{c}\text { Ovary } \\
\text { length, } \mathrm{mm}\end{array}$ & $\begin{array}{c}\text { Ovary } \\
\text { width, mm }\end{array}$ & \multicolumn{4}{|c|}{$\begin{array}{c}\text { Diametr of follicles, } \mu \mathrm{m} ; \\
\mathrm{n} \text { - number of structures per group }\end{array}$} \\
\hline $\begin{array}{l}\text { N/animal } \\
\text { groups }\end{array}$ & & & & $\begin{array}{c}\text { Primordial } \\
(\mathrm{n}=28)\end{array}$ & $\begin{array}{l}\text { Primary } \\
(\mathrm{n}=15)\end{array}$ & $\begin{array}{l}\text { Tertiary } \\
(\mathrm{n}=20)\end{array}$ & $\begin{array}{l}\text { Graafian } \\
(\mathrm{n}=15)\end{array}$ \\
\hline $\begin{array}{l}\text { Control } \\
(\mathrm{n}=10)\end{array}$ & $\begin{array}{r}17.2 \\
\pm 1.2 \\
\end{array}$ & $\begin{array}{r}29.5 \\
\pm 2.8 \\
\end{array}$ & $\begin{array}{r}21.4 \\
\pm 1.7 \\
\end{array}$ & $\begin{array}{r}26.6 \\
\pm 1.9 \\
\end{array}$ & $\begin{array}{r}51.0 \\
\pm 4.8 \\
\end{array}$ & $\begin{array}{l}265.3 \\
\pm 48.9 \\
\end{array}$ & $\begin{array}{r}1761.9 \\
\pm 115.4 \\
\end{array}$ \\
\hline $\begin{array}{l}\text { Experimental } \\
(\mathrm{n}=10)\end{array}$ & $\begin{array}{r}18.6 \\
\pm 1.5\end{array}$ & $\begin{array}{r}35.9 \\
\pm 1.8\end{array}$ & $\begin{array}{l}24.8 \\
\pm 2.2\end{array}$ & $\begin{array}{l}28.2 \\
\pm 1.0\end{array}$ & $\begin{array}{r}82.4 \\
\pm 9.2\end{array}$ & $\begin{array}{l}505.1 \\
\pm 70.1\end{array}$ & $\begin{array}{l}1587.9 \\
\pm 98.2 \\
\end{array}$ \\
\hline $\begin{array}{l}\text { P-value to } \\
\text { the control }\end{array}$ & 0.47 & 0.04 & 0.17 & 0.054 & 0.03 & 0.01 & 0.068 \\
\hline
\end{tabular}
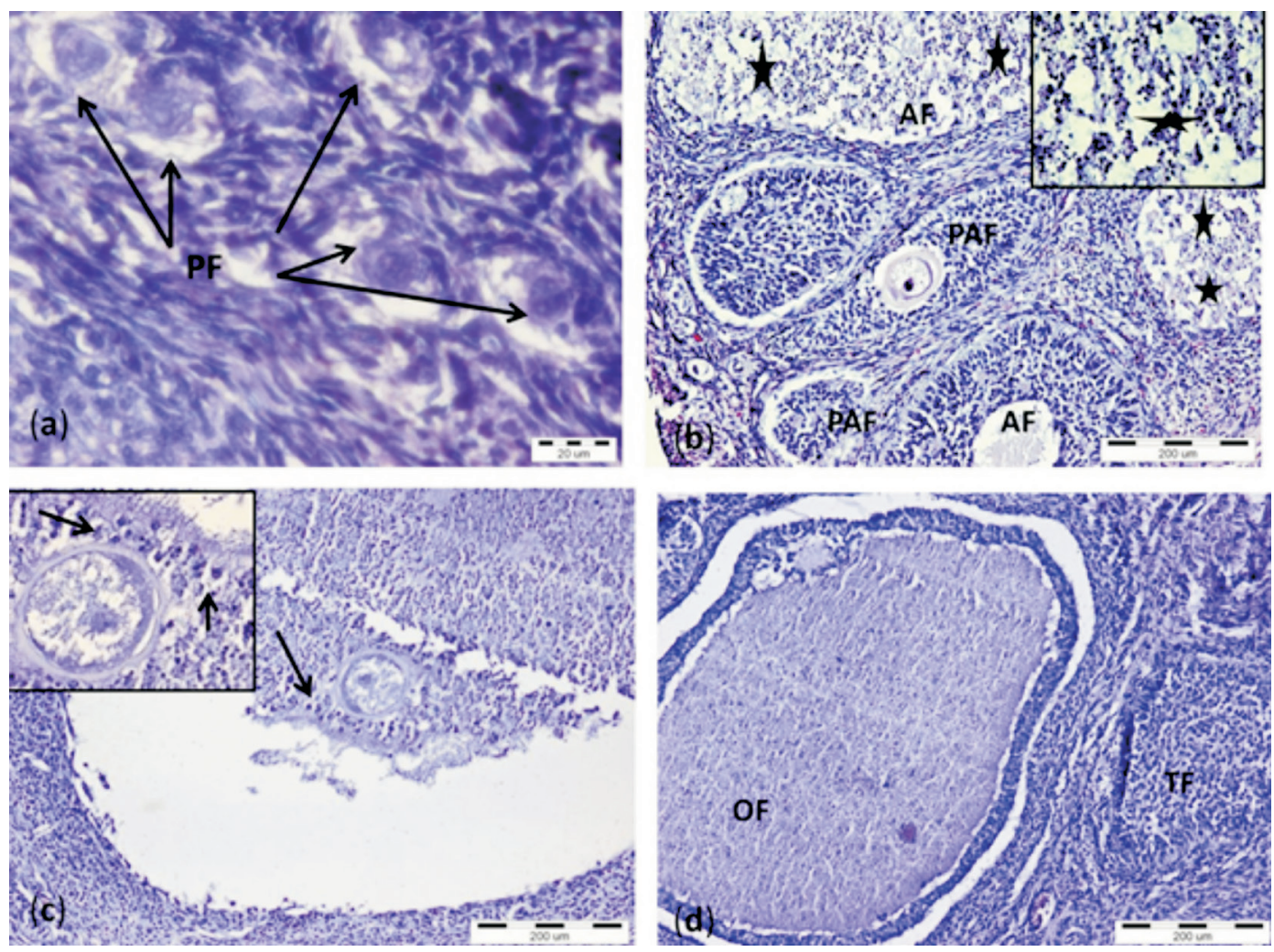

Fig. 1. Folliculogenesis in the ovaries of growing gilts - a-c) supplemented with drone brood, d) control. a) pool of primordial follicles (PF); $\times 100$; b) pool of developing follicles - preantral (PAF) and antral (AF), asterisks pycnotic bodies in the large antral follicles; $\times 20$; insert - pycnotic bodies, $\times 40$; c) Graafian follicle with signs of atresia ; arrows - pycnotic bodies; $\times 20$; insert - oocyte, $\times 40$.; d) healthy ovulatory (OF) and tertiary follicle (TF) ; $\mathrm{H} \& \mathrm{E}, \times 20$.

The experimental animals had more pools of primordial follicles (Fig. 1a) involved in intensive growth (Fig. 1b) up to the antral stage. However, the large follicles at the Graafian stage showed some signs of atresia (Fig. 1b and c). The diameter of the primary and tertiary follicles was significantly higher in DBH-supplemented animals compared to the controls (Table 3). The small number of secondary follicles observed did not allow for accurate statistical analysis of this follicle class. Graafian follicles in the treated animals had a tendency to decrease in diameter compared to the controls $(\mathrm{P}=0.068)$. 


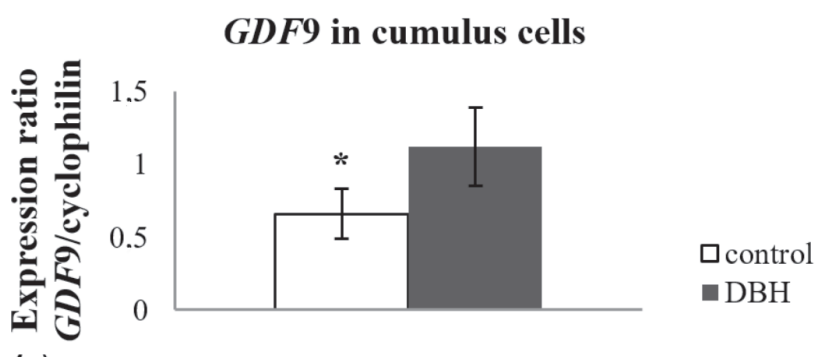

(a)

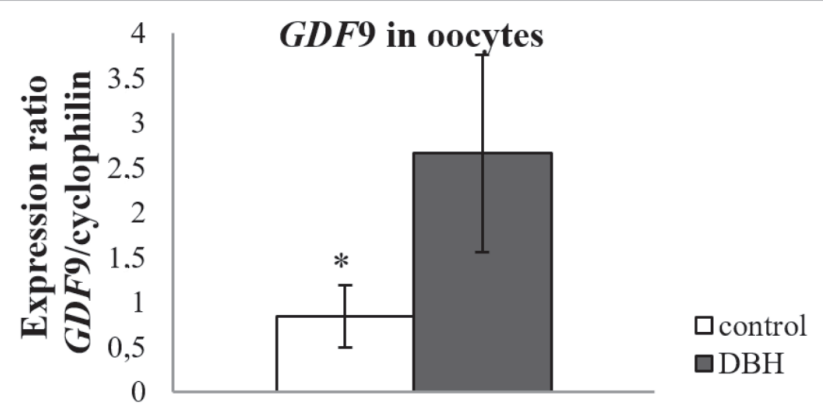

(b)

Fig. 2. GDF9 mRNA expression in the oocytes (a) and cumulus cells (b) of growing gilts. Total RNA was extracted from the oocytes and cumulus cells and subjected to real-time PCR to determine the mRNA levels of GDF9. The expression of mRNA was normalized to the expression of the housekeeping gene - pig cyclophilin. Data represent the mean $\pm \mathrm{SD}$ of the combined results from the analysis of ten animals from each group in three replications (*- significance $\mathrm{P}<0.05$, compared to control).
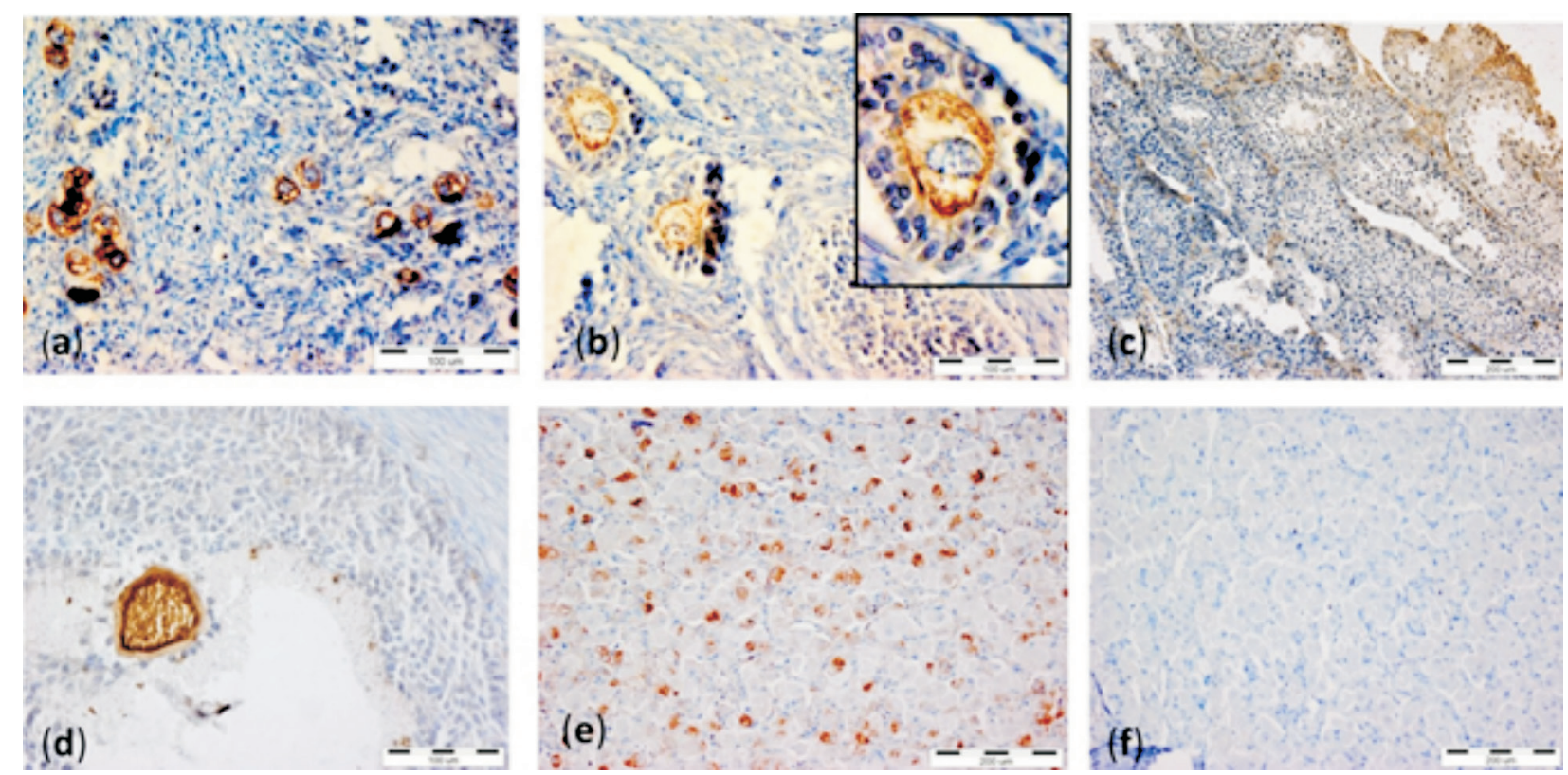

Fig. 3. Expression of the GDF9 protein at different stages of follicular development in the ovaries of DBH- treated gilts: a) oocytes of the primordial and primary follicles, $\times 40$; b) oocytes and granulosa cells of the secondary and tertiary follicle, $\times 40$, insert - secondary follicle, $\times 100$; c) positive control for the antibody, cat testis, $\times 20$; d) oocyte in the antral follicle, $\times 40$; e) corpus luteum, $\times 40$; f) negative control of the antibody, corpus luteum in pig ovary, $\times 40$. H counterstaining. 

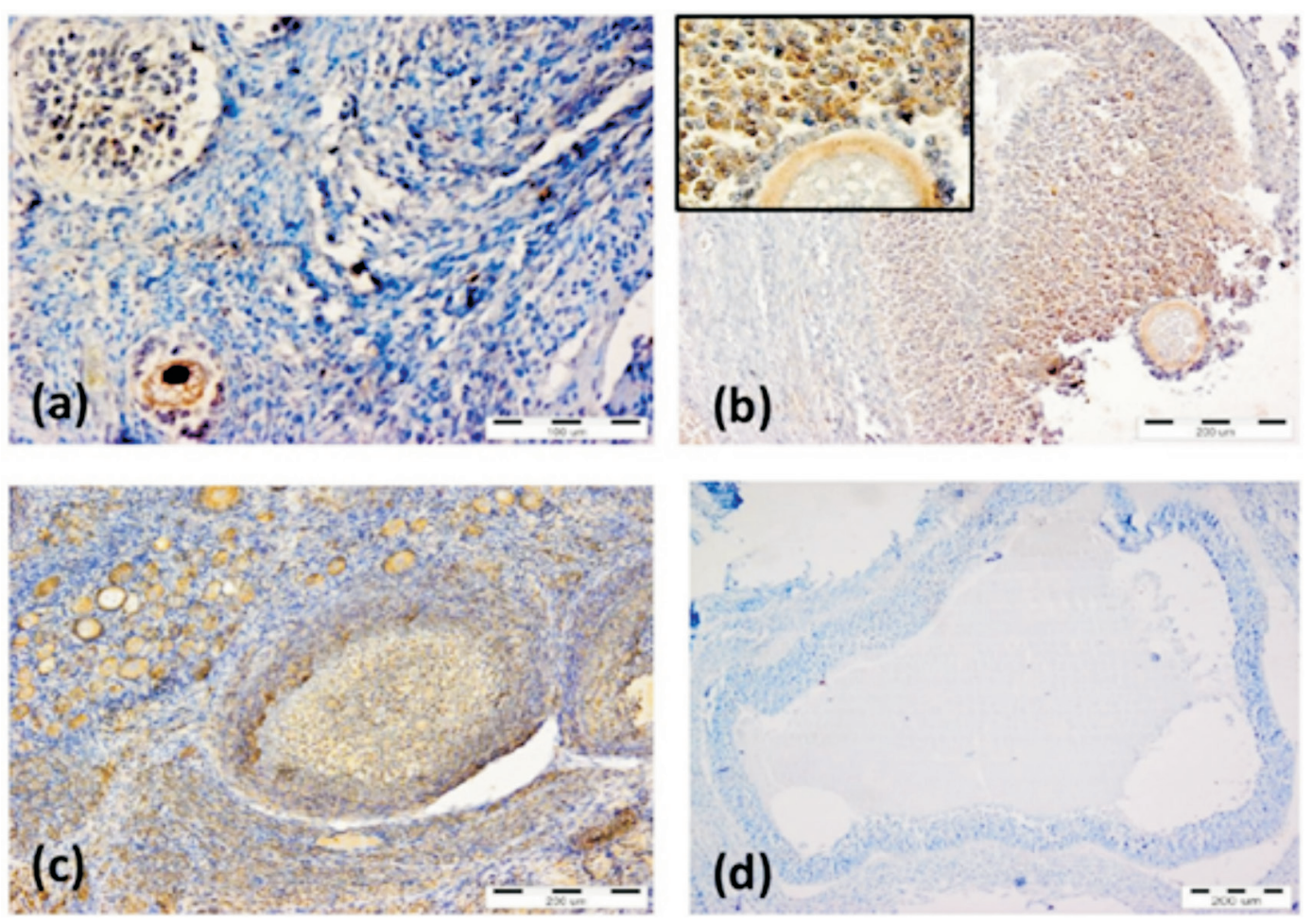

Fig. 4. Expression of BMP15 protein in the ovary of DBH- treated gilts: a) oocyte of secondary and granulose cells of tertiary follicles, $\times 40$; b) oocyte and granulose cells of the Graafian follicle, $\times 20$; insert $-\times 40$; c) positive control for the antibody, rat ovary, $\times 20$; d) negative control for the antibody, pig ovulatory follicle, $\times 10$. H counterstaining.

The expression of growth factor BMP15 at the mRNA level was not significantly different in DBH-supplemented and control groups in both oocytes and cumulus cells (data not shown). In contrast, the level of GDF9 mRNA transcripts was markedly higher in the oocytes and cumulus cells of the DBH-treated animals compared to the controls (Fig. 2).

\section{Discussion}

Although a significant effect of $25 \mathrm{mg} / \mathrm{kg} /$ forage DBH on the enhancement of DW and ADG was only observed on day 145 , these parameters showed a noticeable tendency to increase in DBH-treated gilts throughout the whole experimental period. This is in agreement with our results for pigs in farm conditions (BORJAEV et al., 2018).

A high content of nutrients such as amino acids, proteins, lipids, and sugars (ISIDOROV et al., 2016; BALKANSKA et al., 2014) ensures the energy value
The ovaries of treated gilts showed clear and intense immunostaining for the GDF9 protein in the oocytes at all stages of follicular development, including the corpus luteum stage (Fig. 3). High intensity immunostainning was also observed for the BMP 15 protein in the primary follicles and in the oocytes and cumulus cells of the large antral follicles in the ovaries of animals fed with DBH (Fig. 4).

of the DBH and could explain its growth promoting effects. Our results also support data reported for male broiler growth. (YÜCEL et al., 2011; ALTAN et al., 2013). In addition, anabolic changes may be provoked by ecdysteroids contained within DBH, which can exert various pharmacological effects in mammals (DINAN and LAFONT, 2006). DINAN and LAFONT (2006) reported that the ecdysteroids can affect protein synthesis, as well as lipid and carbohydrate metabolism, and that the ecdysteroid- 
induced effects are more pronounced in animals that are still growing. In conjunction with this, our experiment showed that a higher average daily gain in treated gilts was observed in the earlier stages of development (on day 90). It has also been reported that the power of the ecdysteroid effects increases in the presence of additional proteins (DINAN and LAFONT, 2006). This means that the high protein content in $\mathrm{DBH}(>20 \%$,), together with ecdysteroids, makes it an ideal anabolic supplement (ISIDOROV et al., 2016). The observed increase in muscle fiber size (with 8\%) in the DBH-supplemented animals is in agreement with the results reported by SERES et al. (2014), which were performed on male rats receiving crude drone milk. The authors described a significant increase in the weight of the levator ani muscle in treated group (SERES et al., 2014). This effect is likely mediated by suppression of the growth factor GDF8 (miostatin) and activation of protein synthesis by ecdysteroids (MCPHERRON et al., 1997; LIN et al., 2002). Additionally, DBH is a source of calcium (BURMISTROVA et al., 2014), which might trigger the autocrine/paracrine growth of skeletal muscle in higher doses (GORELICKFELDMAN et al., 2010).

For the first time our results provide evidence that the growth promoting properties of the DBH impact folliculogenesis in the ovaries of gilts at morphological and gene expression level. The weight of the gilt ovaries did not change, but their length increased $(\mathrm{P}<0.05)$. Expressed in the ovaries, BMPs and GDFs are very important regulators of folliculogenesis, oogenesis and ovarian functions in many species (CASTRO et al., 2016). An imbalance in any of these intra-ovarian factors may lead to abnormal follicular development and dysfunction of oocyte maturation. In our experiment, we established that expression of GDF9 mRNA increased and that both BMP15 and GDF9 proteins produced intensive immunostainning signals in the oocytes and cumulus cells of DBH-treated gilts. These results correspond with histological findings in the ovaries of experimental animals. A larger number of primordial follicles, involved in development, as well as enlarged primary and tertiary follicles were observed in the ovaries of the gilts fed with DBH. GDF9 and BMP15, secreted by the oocytes, stimulate the growth of ovarian follicles through primordial follicle recruitment, granulosa cell proliferation and differentiation, and steroid synthesis (SU et al., 2008; ORISAKA et al., 2009). However, the overexpression of these growth factors can have dual effects on folliculogenesis in the ovaries of gilts. In the ovaries of experimental animals we observed a decrease in the size of Graafian follicles, along with signs of atresia. A study by GUTHRIE et al. (1995) had previously shown that atresia of pig follicles may be provoked by an imbalance between locally produced estrogen and androgen, particularly, due to a decrease in estradiol-17 $\beta$ production. We can speculate what may be the cause of suppression of estradiol-17 $\beta$ production and subsequent atresia in our DBH-supplemented gilts. On one hand, according to LAN et al. (2003), the overexpression of GDF9 and BMP15 in mice can cause a decrease in estradiol-17 $\beta$ production by granulosa cells and a prolonged estrous cycle. Our experimental animals showed an increase in GDF9 expression as well. On the other hand, another mechanism of estradiol-17 $\beta$ reduction might stem from the fact that DBH is a donor of an array of steroids, including estradiol, progesterone, and testosterone (BURMISTROVA et al., 2014; SHOINBAYEVA et al., 2015). In particular, all current reports underline the predominant presence of estradiol in $\mathrm{DBH}$, obtained at larvae stage. This exogenous estradiol could suppress the production of the endogenous one, through gonadotropin negative feedback. Another reason for atretic changes in the large follicles could be the suggested inhibition of the growth factor GDF8. The increase in the loin eye area in our experimental animals is indirect proof of GDF8 suppression. Moreover, recent scientific data have elucidated the important role of miostatin (GDF8) in follicular development. They showed that GDF8 may enhance FSH-induced aromatase/ estradiol production in granulosa cells (CHANG et al., 2016). In any case, the decrease in size and signs of atresia in the ovulatory follicles, likely point to the insufficient level of the endogenous estradiol in the ovaries of DBH -supplemented animals. 


\section{Conclusion}

Our results show that DBH exerts a clear anabolic effect in gilts due to a combination of nutritional components such as proteins, lipids and sugars, and bioactive substances such as esters of fatty acids, ecdysteroids and steroidal hormones. This means that DBH may be considered to be a valuable feed additive in animal husbandry for the purposes of increasing meat production. However, the application of DBH in female animals, used for reproductive purposes, has to be dose- and time limited due to the ability of DBH to alter the expression of ovarian growth factors GDF9 and BMP15, which are responsible for proper follicular development and ovulation. The pathways through which DBH affects the female reproductive system still need to be elucidated. This is important since patented DBH products are being recommended for treatment of sexual problems for both males and females. Further research will allow for definition of the appropriate dose and duration of DBH treatment beneficial for females of different species, while also minimizing any harmful effects.

\section{References}

ABADJIEVA, D., E. KISTANOVA (2016): Tribulus terrestris alters the expression of growth differentiation Factor 9 and bone morphogenetic Protein 15 in rabbit ovaries of mothers and F1 female offspring. PLoS ONE 11(2).

DOI: 10.1371/journal.pone.0150400. eCollection 2016

ALTAN, O., B. YÜCEL, Z. AÇIKGÖZ, C.SEREMET, M. KÖSOĞLU, N. TURGAN, A.M. OZGÖNÜL (2013): Apilarnil reduces fear and advances sexual development in male broilers but has no effect on growth. Br. Poult. Sci. 54, 355-361.

DOI: $10.1080 / 00071668.2013 .791382$

BALKANSKA, R., I. KARADJOVA, M. IGNATOVA (2014): Comparative analyses of chemical composition of royal jelly and drone brood. Bulg. Chem. Commun. 6, 412-416.

BURMISTROVA, L., N. BUDNIKOVA D. MITROFANOV (2014): Hormones from the different age of Apis mellifera drone brood. Proceedings of the $17^{\text {th }}$ Russian scientific conference "Apitherapy today ", Ribnoe, Russia, 25-26 April, 2014, pp. 107-112 (in Russian).

BORJAEV, G.I., E.V. ZDOROVEGA, A.S.LOVCHIKOV, S. S. BELYAKOV (2018): Effect of feed additives on the basis of the drone brood on the productive indicators of fattening pigs. Proceedings of the Russian scientific conference „The role of an university science in the solution of the problems in the agro industrial complexes", Penza, Russia, 24-25 October, 2018, pp. 187-190 (in Russian).
CASTRO, F., M. CRUZ, C. LEAL (2016): Role of Growth Differentiation Factor 9 and Bone Morphogenetic Protein 15 in Ovarian Function and Their Importance in Mammalian Female Fertility. Asian Austral J. Anim. Sci. 29, 1065-1074.

DOI: 10.5713/ajas.15.0797

CHANG, H.M., L. FANG, J.C. CHENG, E.L. TAYLOR, Y.P. SUN, P.C. LEUNG, (2016): Effects of growth differentiation factor 8 on steroidogenesis in human granulosa-lutein cells. Fertil and Steril. 105, 520-528.

DOI: 10.1016/j.fertnstert.2015.10.034

DAOUD, N., K. MAHROUS, O. EZZO (2012): Feed restriction as a biostimulant of the production of oocyte, their quality and GDF-9 gene expression in rabbit oocytes. Anim. Reprod. Sci. 136, 121-127.

DOI: 10.1016/j.anireprosci.2012.09.011

DINAN, L., R. LAFONT (2006): Effects and applications of arthropod steroid hormones (ecdysteroids) in mammals. J. Endocrinol. 191, 1-8.

DOI: 10.1677/joe.1.069000022-0795/06/0191-001

GORELICK-FELDMAN, J., W. COHICK, I. RASKIN (2010): Ecdysteroids elicit a rapid $\mathrm{Ca} 2+$ flux leading to $A k t$ activation and increased protein synthesis in skeletal muscle cells. Steroids 75, 632-637.

DOI: 10.1016/j.steroids.2010.03.008

GRIFFIN, J., B. EMERY, I. HUANG, C.M. PETERSON, D.T. CARRELL (2006): Comparative analysis of follicle morphology and oocyte diameter in four mammalian species (mouse, hamster, pig, and human). J. Exp. Clin. Assist. Reprod. 3, 2.

DOI: $10.1186 / 1743-1050-3-2$

GUTHRIE, H., R. GRIMES, B. COOPER, J.M. HAMMOND (1995): Follicular Atresia in Pigs: Measurement and Physiology. J. Anim. Sci. 73: 2834-2844.

DOI: $10.2527 / 1995.7392834 x$

HUIS, A. (2013): Potential of Insects as Food and Feed in Assuring Food Security. Annu. Rev. Entomol. 58: 563-583. DOI: 10.1146/annurev-ento-120811-153704

ISIDOROV, V., S. BAKIER, M. STOCKI (2016): GC-MS investigation of the chemical composition of honeybee drone and queen larva homogenate. J. Apicul. Sci. 60, 111120.

DOI: $10.1515 / \mathrm{JAS}-2016-0011$

LAFONT, R., J.L.PENNETIER, M.ANDRIAN JAFINTRIMO, J. CLARET, J. F. MODDE, C. BLAIS (1982): Sample processing for high-performance liquid chromatography of ecdysteroids. Journal of Chromatography A 236, 137-149. DOI: 10.1016/S0021-9673(00)82507-8

LAN, Z., P. GU, X. XU, K.J., JACKSON, F.J. DEMAYO, B.W. O'MALLEY, A.J. Cooney (2003):GCNF-dependent repression of BMP-15 and GDF-9 mediates gamete regulation of female fertility. The EMBO Journal 22, 40704081.

DOI: $10.1093 / \mathrm{emboj} / \mathrm{cdg} 405$ 
LIN, J., H. ARNOLD, M. DELLA-FERA, M. J. AZAIN, D. L. HARTZELL, C.A. BAILE (2002): Myostatin knockout in mice increases myogenesis and decreases adipogenesis. Biochem. Biophys. Res. Commun. 291, 701-716.

DOI: $10.1006 /$ bbrc. 2002.6500

MCPHERRON, A., A. LAWLER, S. LEE (1997): Regulation of skeletal muscle mass in mice by a new TGF-beta superfamily member. Nature 38, 83-90.

DOI: $10.1038 / 387083 \mathrm{a} 0$

MEDA, A., C. E. LAMIEN, J. MILLOGO, M. ROMITO, O. G. NACOULMA (2004): Therapeutic uses of honey and honeybee larvae in Central Burkina Faso. J. Ethnopharm. 95, 103-107.

DOI: 10.1016/j.jep.2004.06.016

MUTSAERS, M., H. VAN BLITTERSWIJK, L. VAN'T LEVEN, J. KERKVLIET, J. VAN DE WAERDT (2005): Brood. In: Bee products: properties, processing and marketing (Mutsaers M, Ed). AgromisaFoundation, Wageningen, The Netherlands, pp. 41-43.

NARUMI, S.( 2004): Honeybee brood as a nutritional food. Honeybee Science 25,119-124.

ORISAKA, M., K. TAJIMA, B. TSANG, F. KOTSUJI (2009): Oocyte-granulosa-theca cell interactions during preantral follicular development. J. Ovarian Res. 2, 2-9.

DOI: $10.1186 / 1757-2215-2-9$

OTSUKA, F., K. MCTAVISH, S. SHIMASAKI (2011): Integral role of GDF-9 and BMP-15 in ovarian function. Mol. Reprod. Dev. 78, 9-21.

DOI: $10.1002 / \mathrm{mrd} .21265$

RODGERS, J.B., L.C. SHERWOOD, B.F. FINK, R.C. SADOVE (1993): Estrus detection by using vaginal cytologic examination in miniature swine. Lab. Anim. Sci. $43,597-602$
SERES, A., E. DUCZA, M. BÁTHORI, A. HUNYADI, Z. BÉNI, M. DÉKÁNY, J. HAJAGOS-TÓTH, J. VERLI, R. GÁSPÁR (2014): Androgenic effect of honeybee drone milk in castrated rats: roles of methyl palmitate and methyl oleate. J. Ethnopharm. 153, 446-453.

DOI: $10.1016 /$ j.jep.2014.02.050

SERES, A., E. DUCZA, M. BATHORI, A. HUNYADI, Z. BÉNI, M. DÉKÁNY, R. GASPAR (2013): Raw drone milk of honeybee elicits uterotrophic effect in rat: evidence for estrogenic activity. J. Med. Food. 16, 404-409.

DOI: $10.1089 / \mathrm{jmf} .2012 .0232$

SHOINBAYEVA, K., T. OMIRZAK, T. BIGARA, A. ABUBAKIROVA, A. DAUYLBAY (2017): Biologically active preparation and reproductive function of stud rams. Asian J Pharm. 11, 184-190.

DOI: 10.22377/ajp.v11i03.1402

SHOINBAYEVA, K., A. RUSTENOV, N. ELEUQALIEVA, T. OMIRZAK, U. AKHANOV (2015): Improving reproductive qualities of pigs using the drone brood homogenate. Biol. Med. 7, 1-3.

SU, Y., K. SUGIURA, K. WIGGLESWORTH, M. J. O'BRIEN, J. P. AFFOURTIT, S. PANGAS, M. M. MATZUK, J. J. EPPIG (2008): Oocyte regulation of metabolic cooperativity between mouse cumulus cells and oocytes: BMP15 and GDF9 control cholesterol biosynthesis in cumulus cells. Dev. 135, 111-121. DOI: $10.1242 / \mathrm{dev} .009068$

YÜCEL, B., Z. AÇIKGÖZ, H. BAYRAKTAR, C. SEREMET (2011): The effect of Apilarnil (drone bee larvae) administration on growth performance and secondary sex characteristics of male broilers. J. Anim. Vet. Adv. 10, 2263-2266.

DOI: 10.3923/javaa.2011.2263.2266

Received: 26 November 2019

Accepted: 8 January 2020

KISTANOVA, E., E. ZDOROVEVA, M. NEVITOV, A. NOSOV, M. VYSOKIKH, I. SUKHANOVA, P. VISHNYAKOVA, D. ABADJIEVA, D. ANKOVA, P. RASHEV, G. BORYAEV: Utjecaj hranidbe s dodatkom trutovskog legla na folikulogenezu u nazimica. Vet. arhiv 90, 583-592, 2020.

\section{SAŽETAK}

Biološka svojstva pčelinjeg trutovskog legla čine ga idealnim dodatkom za poboljšanje rasta u stočarstvu umjesto zabranjenih hormonskih anabolika i antibiotika. Ipak, utjecaj trutovskog legla na jajnike u sisavaca još uvijek nije dovoljno istražen. $\mathrm{U}$ ovom se radu analiziran je utjecaj homogenata trutovskog legla (DBH) u prehrani nazimica na folikulogenezu. Ženke pasmine veliki jorkšir u dobi od 35 dana nasumično su podijeljene u dvije skupine po 10 životinja, s jednakim osnovnim prehrambenim obrokom. Pokusnoj skupini u krmu je dodavano $25 \mathrm{mg} / \mathrm{kg} \mathrm{DBH}-\mathrm{a}$ tijekom 180 dana, nakon čega su životinje usmrćene te je učinjena morfometrijska, histološka i imunohistokemijska procjena jajnika. Zatim je u oocitama i stanicama kumulusa RT-PCR-om analiziran izražaj faktora rasta jajnika, BMP15 i GDF9. U skupini s dodatkom prehrani DBH ustanovljen je znakovit porast tjelesne mase i prosječnog dnevnog prinosa 145. dan. Povećana je i dužina jajnika u pokusnih životinja. U životinja hranjenih dodatkom pronađeno je više nakupina primordijalnih folikula uključenih u intenzivan rast, kao i veći promjer primarnih i tercijarnih folikula. Ovi su rezultati u skladu s porastom izražaja GDF9 mRNA u oocitama i stanicama kumulusa. Istodobno su opaženi znakovi atrezije u Graafovim folikulima pokusnih životinja. Dodatak prehrani DBH stimulira rane stadije folikulogeneze u nazimica, ali uzrokuje atreziju u posljednjem stadiju folikularnog razvoja.

Ključne riječi: jajnici nazimica; homogenat trutovskog legla; BMP15; GDF9 